Review Article

\title{
Diapriinae Wasps (Hymenoptera: Diaprioidea: Diapriidae) Associated with Ants (Hymenoptera: Formicidae) in Argentina
}

\author{
Marta S. Loiácono, ${ }^{1}$ Cecilia B. Margaría, ${ }^{1,2}$ and Daniel A. Aquino' \\ ${ }^{1}$ División Entomología, Facultad de Ciencias Naturales y Museo, Universidad Nacional de La Plata, \\ 1900 La Plata, Buenos Aires, Argentina \\ ${ }^{2}$ Facultad de Ciencias Agrarias y Forestales, Universidad Nacional de La Plata, 1900 La Plata, Buenos Aires, Argentina \\ Correspondence should be addressed to Marta S. Loiácono; loiacono@fcnym.unlp.edu.ar
}

Received 19 December 2012; Revised 15 February 2013; Accepted 20 February 2013

Academic Editor: Jean-Paul Lachaud

Copyright () 2013 Marta S. Loiácono et al. This is an open access article distributed under the Creative Commons Attribution License, which permits unrestricted use, distribution, and reproduction in any medium, provided the original work is properly cited.

We provide an overview of diapriid wasps associated with ants in Argentina and the diversity of interactions they have developed with their hosts. As a result, we report 16 species of nine genera of Diapriinae, two new geographic distributions, three new association records, illustrations, and photographs. We highlight myrmecophile symphylic species, with a high degree of integration with the host ants, adaptation being morphological and behavioral. A table with diapriid species and ant hosts is given.

\section{Introduction}

Diapriids are primary endoparasitoids of larvae-pupae or pupae, principally of dipterans, but a number of species are closely associated with ant nests. However, there are few behavioral data on host-diapriid myrmecophile interactions. Huggert and Masner [1] hypothesized that the ancestors of diapriines guests changed from Diptera to Formicidae. The intermediates in the presumed sequence of hosts seem to be the numerous synoeketic Diptera living in the refuse depot and bivouacs of various army ants of the subfamily Ecitoninae. Diapriines females, in the search for potential hosts, would have progressively integrated with formicids. According to Masner (personal communication) this change would have occurred more frequently in the Neotropical region where these ants have high distribution. The guests switch mechanism has determined morphological and behavioral specialization, manifested by the degree of integration of diapriines to ant colonies. These symphyles are often highly adapted to their hosts, exhibiting morphological and behavioral adaptations to living with ants (extensive morphological mimicry of the host ants coloration, ocellus regression, similar sculpture, presence of appeasement substances in specialized structures and trichomes, trophallaxis, etc.), which aid them in avoiding detection and/or aggression by host ants. Ants seem to have preference to lick certain parts of diapriid body to get exudates [2]. The adaptations include secondary apterism in which the wings of wasps are bitten off by either the parasite itself or its host. During the alate phase, the adults probably disperse, as the alate individuals, caught by sweeping, in Malaise traps and significantly by light traps indicating also the nocturnal activity in this phase of life [2]. The secondary apterism occurs in several species of diapriines, for example, Asolenopsia rufa Kieffer, Bruchopria pentatoma Kieffer, Bruchopria hexatoma Kieffer, Notoxoides pronotalis (Borgmeier), herein studied.

The current knowledge indicates that only a few diapriids are parasitoids of ant brood, attacking as solitary or gregarious koinobiont endoparasitoids of the host larvae, and worker and/or reproductive immature stages can be parasitized. From 121 diapriine species in 34 genera that had been collected in association with ants, development of immature stages as parasitoids of ant larvae has been demonstrated for only 26 species in seven genera, most of which are only known at the level of morphospecies [3]. There are only two species and one morphospecies recorded in Argentina as ant parasitoids [4].

A large number of diapriine wasps became associated with various groups of ants in Central and South America. 
The associations are especially well developed with army ants (Ecitonini) and leaf cutting ants (Attini) with some 20 genera of Diapriinae already involved [5]. The vast majority of these species belong to Diapriini, although there are some exceptions like Bruchopria species that belong to the tribe Spilomicrini [6].

The New World fungus-growing ants (Hymenoptera: Formicidae: Attini) are especially diverse in the tropics. As true for the most social insects, they accumulate significant stores of resources within their nests, attracting a diverse array of predators, microbial pathogens, and parasites [7]. We studied aspects of the intensity and prevalence of these littleknown diapriine wasps that attack the larvae of the fungusgrowing ant, Acromyrmex lobicornis Emery, and noted a remarkably diverse community of parasitoids within host population from four localities of La Pampa, Argentina [4, 8]. In some cases, the rates of parasitoidism can reach high levels. Loiácono et al. [4] collected 1560 wasps (adults and immatures) from 430 parasitized larvae from three partial colonies of Acromyrmex, which shows how prevalent these wasps can be in attacking the ants. Fernández-Marin et al. [9] found that between $27 \%$ and $70 \%$ of the colonies of two species of Cyphomyrmex Mayr were parasitized by one species in Puerto Rico and by up to four concurrent morphospecies of diapriids in Panama. Similarly, Pérez-Ortega et al. [7] reported that another fungus-growing ant, Trachymyrmex cf. zeteki, was attacked by a diverse community of diapriids in Panama, with a mean intensity of larval parasitism per ant colony of 33.9\%, and prevalence across all ant populations of 27.2\%. Lachaud and Pérez Lachaud [3], based on the abundance and success in attacking ants, considered that diapriids and another group of microhymenopterans, the eucharitids, seem excellent potential models to explore how parasitoids impact ant colony demography, population biology, and ant community structure [3].

In Argentina, the study of myrmecophiles has attracted the attention of several scientists in the last two centuries. Carlos Bruch (1869-1943), a German naturalist selected by F. Moreno-first Director of Museo de La Plata-to organize its collections, was a pioneer of the entomological studies; it is important to remark his ability as a photographer and scientific illustrator, and his observations regarding special associations and behaviors of ants and beetles: termitophily and myrmecophily [10, 11]. Jean-Jacques Kieffer (1857-1925), a French entomologist who specialized in the study of parasitoids of insects, based his studies on Bruch's material and published articles about diapriines associated with ants [12, 13]. Alejandro Ogloblin (1891-1967), a Russian entomologist researcher at "Estación Experimental de Loreto" (Misiones, Argentina), collected there numerous diapriid wasps associated specially with myrmicine ants $[14,15]$. Luis De Santis (1914-2000) catalogued associations between diapriids and ants [16, 17] and reported new geographic distributions [18]. Marta Loiácono and colleagues studied Neotropical myrmecophiles diapriids and their interactions with ants [4, 7, 8, 15, 19-29].

In this paper, we provide an overview of the diversity of diapriid wasps associated with ants in Argentina and the diversity of interactions they have developed with their hosts.

\section{Material and Methods}

Specimens for this study were reared in laboratory [4] or collected from ant nests, killed in alcohol, and mounted on cards or microscopic slides for further studies. Observations of the specimens were made through a stereomicroscope Leica S8APO. The photographs were taken by Daniel A. Aquino with a Leica DFC295 camera attached to the stereomicroscope. Digital images were mounted using open software CombineZM [30] and enhanced using Photoshop. Scanning micrographs were taken with a JEOL JSMT100 at Museo de La Plata operating at $15 \mathrm{KV}$.

Sharkey [31] was followed for the higher-level phylogeny of the Hymenoptera order, Bolton for ant valid names [32], Masner and García [5] for diapriid systematics, and Yoder et al. web site [33] for interactive keys and links.

Diapriid and ant specimens examined in this study are deposited at Museo de La Plata (Buenos Aires, Argentina). Most of them were collected and determined by Bruch and Ogloblin in Argentina. Type material of Szelenyiopria reinchenspergeri (Ferrière) was loan by Hungarian Natural History Museum.

Biology Section includes "hosts" wasps emerged from ant larvae or "associated" wasps found in or near nests or emigration columns of army ants.

\section{Results}

\subsection{Tribe Diapriini Ashmead, 1893 [34]}

3.1.1. Asolenopsia Kieffer, 1921 [12]. Asolenopsia Kieffer, 1921: 36 [12].

Euplacopria Ferrière, 1929: 157 [35].

Distribution. Tropical lowlands of Central and South America [5].

Biology. Associated with ecitonini ants of genus Eciton Latreille, Labidus Jurine and Neivamyrmex Borgmeier [5].

Remarks. Members of Asolenopsia are moderately to highly specialized associates to ecitonine ants [20]. Their wings are primarily developed but subsequently bitten off by ants or cast off spontaneously (alectomy). Winged adults are also collected in light traps [5].

3.1.2. Asolenopsia rufa Kieffer, 1921 [12] (Figure 1(a)). Asolenopsia rufa Kieffer, 1921: 37 [12].

Distribution. Argentina (Córdoba, Entre Ríos, and Santa Fe) $[12,17]$.

Biology. Associated with Neivamyrmex carettei (Forel) [12] (Figure 1(b)).

Material Studied. Syntype, female, dealated, with Neivamyrmex carettei worker, Argentina, Córdoba, Alta Gracia, La Granja, 1-8-IV-1920, Bruch coll.; one female, without date, 


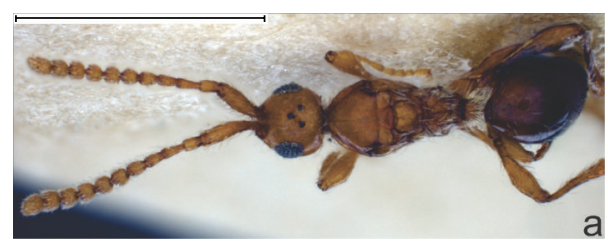

(a)

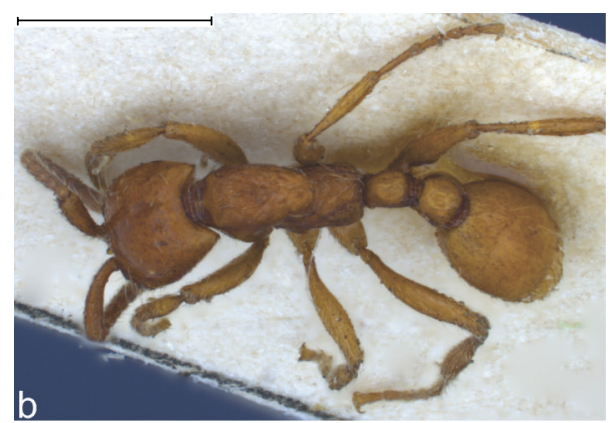

(b)

FIgure 1: (a) Asolenopsia rufa female dealate in dorsal view. (b) Neivamyrmex carettei. Scale: $1 \mathrm{~mm}$.

Santa Fe, Vera y Pintado (Fives Lille), Weiser coll; female alated, Argentina, Misiones, Loreto, without date, Ogloblin coll.

\subsubsection{Basalys Westwood, 1832 [36]. Basalys Westwood,} 1832: 342-344 [36].

Ceratopria Ashmead, 1893: 407, 42 [34].

Acidopria Kieffer, 1913: 442 [37].

Loxotropa auct. nec Foerster, synonymized by Masner, 1964 [38].

Nesopria Muesebeck and Walkley, 1956: 319-419 [39].

Distribution. The genus is well represented in North and South America, rarely in Chile [5].

Biology. Several species were reared from various dipterous hosts, and some were collected in ant nests [5].

\subsubsection{Basalys sp.}

Material Studied. One female and 1 male (microscopic slide) collected with the "Argentine ant," Linepithema humile (Mayr), Argentina, Buenos Aires, J. C. Paz, 11-X-1934, Ogloblin coll.; 1 female (microscopic slide) collected with the Argentine ant Linepithema humile, Argentina, Buenos Aires, J. C. Paz, 8-IX-1945, Bezzi leg.

Biology. Associated with Linepithema humile (new record).

Remarks. Female and male studied were determined by Masner, who wrote a label: "Basalys sp. 우(=Loxotropa auct.) aberrant sp. with !11-segm. ant. ㅇ, Det. L. Masner, '89”; and female specimen: "Basalys sp. o(=Loxotropa auct.) !11segmented antenna, Det. L. Masner, '89." Specimens studied were determined by Ogloblin as a new species of Doliopria,

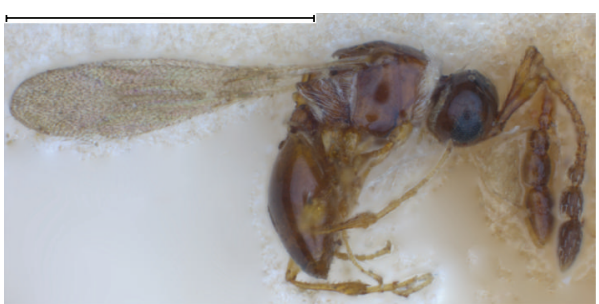

FIgure 2: Doliopria collegii female in lateral view. Scale: $1 \mathrm{~mm}$.

but he did not describe it. We also considered that material studied belong to genus Basalys, as it was established by Masner.

3.1.5. Doliopria Kieffer, 1910 [40]. Doliopria Kieffer, 1910: 48 [40].

Martinica Risbec, 1950: 533 [41].

Distribution. Doliopria is restricted to the New World, with only a few species in the Nearctic region and with a high number of undescribed species in tropical America [5].

Biology. Associated with ecitonini and attini ants [5].

Remarks. Three Neotropical species were described associated with ants $[12,35,40]$; hypothetically they parasitized synoeketic Diptera because they show no specialized morphology [5].

3.1.6. Doliopria collegii Ferrière, 1929 [35] (Figure 2). Doliopria collegii Ferrière, 1929: 164 [35].

Distribution. Argentina (Buenos Aires and Misiones) [18, 35].

Biology. Associated with ecitonini ants, Eciton burchellii (Westwood) and Eciton quadriglume (Haliday) [35].

Material Studied. Two females alated, Argentina, Misiones, Loreto, 20-X-1919 and 18-IX-1923, Ogloblin coll. and det.

3.1.7. Doliopria myrmecobia Kieffer, 1921 [12] (Figure 3(a)). Doliopria myrmecobia Kieffer, 1921: 39 [12].

Distribution. Argentina (Buenos Aires; Misiones, new record) [12].

Biology. Associated with attini ants Acromyrmex lundii (Guérin-Méneville) [12] (Figure 3(b)).

Material Studied. One female, Argentina, Buenos Aires, La Plata, VIII, inside a nest of Acromyrmex lundii, Bruch coll.; 1 female, alated collected with Acromyrmex sp., Argentina, Misiones, Loreto, 3-XI-1928, Ogloblin coll. and det.

3.1.8. Notoxoides Ashmead, 1903 [42]. Notoxoides Ashmead, 1903: 30 [42].

Notoxopria Kieffer, 1910: 39 [40].

Philolestes Kieffer, 1922: 205 [13].

Psilogasteroides Brèthes, 1911: 209-210 [43]. 


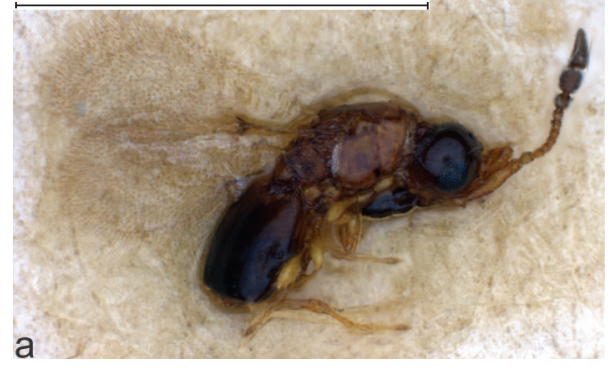

(a)

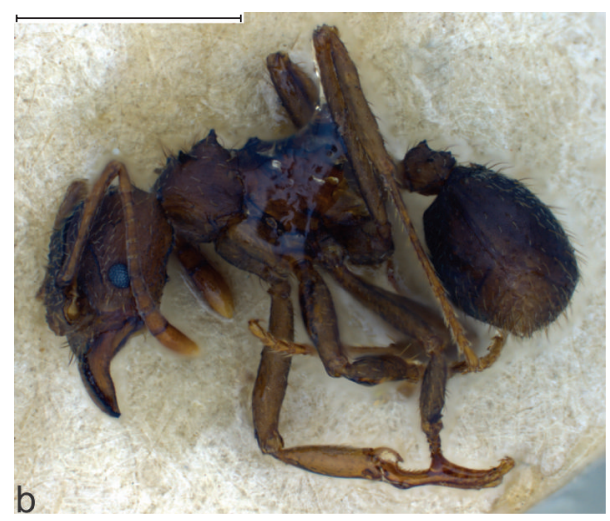

(b)

FIgURE 3: (a) Doliopria myrmecobia female in lateral view. (b) Acromyrmex lundii. Scale: $1 \mathrm{~mm}$.

Distribution. Restricted to lowland rainforests of continental South America [5].

Biology. Members of Notoxoides display some of the most advanced associations with ants. So far, ants of genera Neivamyrmex and Eciton (Ecitonini) were recorded as hosts [19]. Adult wasps are frequently collected in light traps. Wings may be lost to typical alectomy as indicated by shriveled wing rudiments in some specimens [5].

3.1.9. Notoxoides pedissequus (Borgmeier, 1939) [44]. Notoxopria pedissequa Borgmeier, 1939: 538 [44].

Distribution. Argentina (Córdoba) [19].

Biology. Associated with Neivamyrmex pseudops (Forel) [44].

Remarks. Loiácono [20] studied a female alate collected by Bruch in Córdoba province.

3.1.10. Notoxoides pronotalis (Borgmeier, 1939) [44] (Figures 4(a), 4(b), and 5). Philolestes rufus Kieffer, 1922: 205 [13].

Philolestes pronotalis Borgmeier, 1939: 536 [44].

Notoxoides pronotalis: Masner, 1977: 34 [45].

Notoxoides kiefferi Loiácono, 1981: 305, 306 [19].

Distribution. Argentina (Córdoba, Salta, San Luis, and Santiago del Estero) $[19,44]$.

Biology. Associated with Eciton dulcium Forel and Neivamyrmex sulcatus (Mayr) [44].

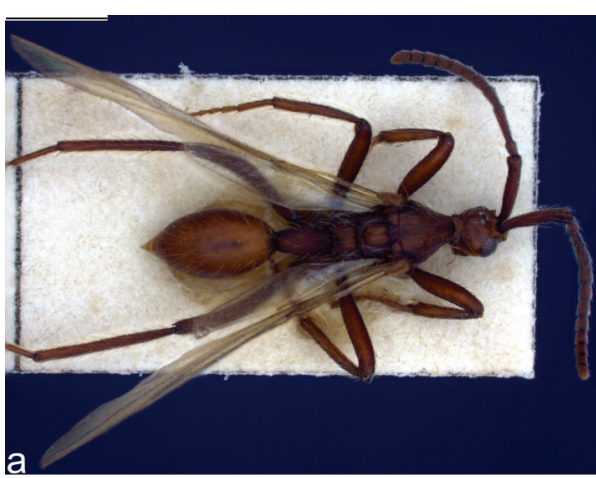

(a)

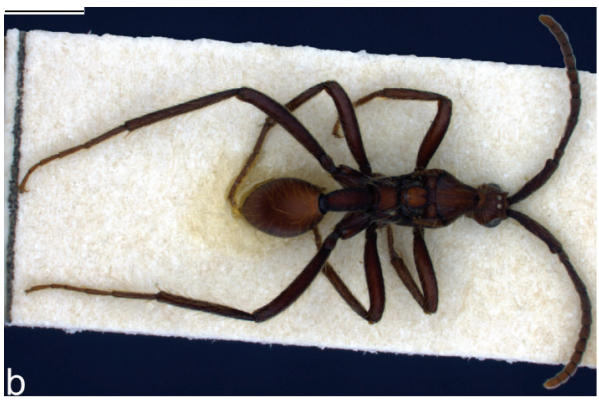

(b)

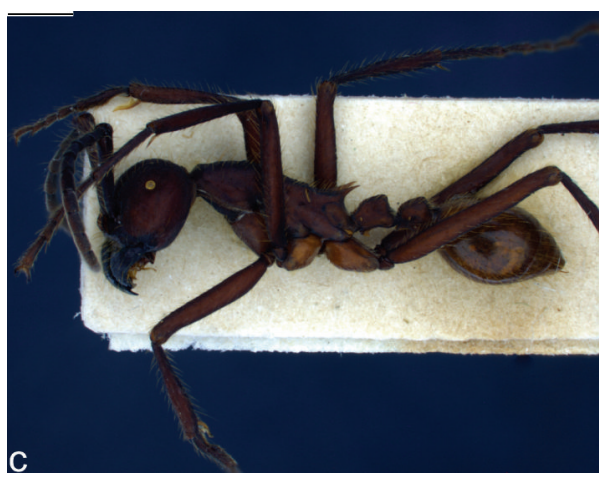

(c)

FIGURE 4: Notoxoides pronotalis female in dorsal view: (a) alate and (b) dealate specimens. Scale: $1 \mathrm{~mm}$. (c) Eciton dulcium collected with Notoxoides pronotalis, in lateral view. Scale: $1 \mathrm{~mm}$.

Material Studied. Syntype, female dealated, collected with Eciton dulcium, Argentina, Córdoba, Alta Gracia, 4-XII-I921, Bruch coll.; 2 syntype females alated, same data as syntype except II-1922, collected with Neivamyrmex sulcatus, Bruch coll. and det.; 21 females dealated, Argentina, Salta, Tartagal, I-1960, Martínez coll., with a Eciton dulcium, and 5 females alated, Argentina, Salta, Pocitos, III-1959, Martínez coll.; 3 females dealated and 1 alated, Córdoba, San Javier, La Paz, 15-31-XII-1928, Bruch coll., with Eciton dulcium; Córdoba, Alta Gracia: 1 female dealated, collected with Eciton dulcium (Figure 4(c)), 4-XII-1922, Bruch coll.; 1 female dealated, without date and collector; 1 female alated, La Granja, 21-VIII1924, Bruch coll.; 2 females dealated, La Granja, 25-I-1925, Bruch coll.; 3 females alated, La Granja, 4-XI-1925, Bruch 


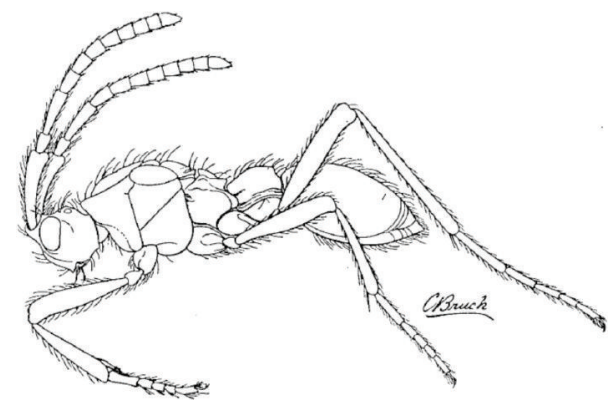

FIgURE 5: Original illustration of Notoxoides pronotalis female in lateral view, by Bruch.

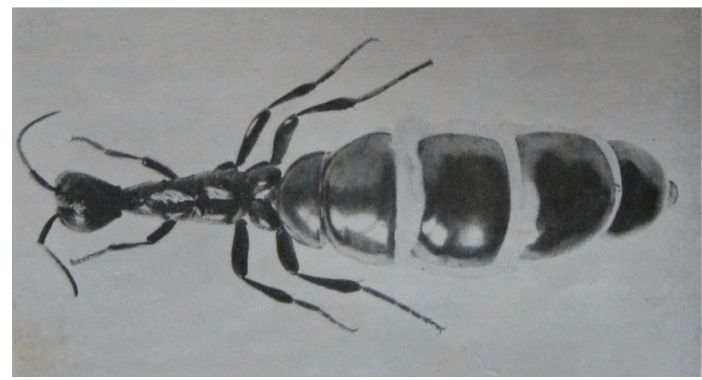

FIGURE 6: Neivamyrmex pseudops, gravid queen in dorsal view, photographed by Bruch.

coll.; 2 females dealated, with Eciton dulcium, La Granja, 4XI-1925, Bruch coll.; 2 females alated with Eciton dulcium, 13-III-1934, Bruch coll.; 3 females alated, without date, Bruch coll.; 1 female dealated; Córdoba, Unquillo, without date and collector; 9 females alated, Córdoba, Unquillo, without date and collector; 1 female with fore wings, Córdoba, Unquillo, without date and collector; 2 females alated, Santiago del Estero, Cerrillos, 2-V-1955, without collector, and 2 females alated, without date, Bruch coll.; 5 females alated, without locality, 21-II-1925, light collected, without collector; 2 females dealated and 3 alated, without locality, 22-II-1925, light collected, without collector; 5 females alated and 1 dealated, without locality, 23-II-1925, light collected, without collector; 1 female alated, without locality, 24-II-1925, light collected, without collector.

Remarks. Bruch always sent to Kieffer diapriid samples to be studied. As we mentioned, he was an excellent scientific illustrator (Figure 5) [46] and an important photographer as is shown in (Figure 6) Neivamyrmex pseudops, ant host of Notoxoides pedisequus [47].

We observed numerous both alate and dealate individuals found dependent on the phase of life. As is mentioned [2], during the alate phase, numerous adults were caught by light traps as we observed in the female material light collected by Bruch.

Lachaud [48] mentioned that ants search actively for some chemical substances produced by glands at the basis of the setae present on the diapriid cuticle; similarly we observed the presence of peculiar neck hairs in N. pronotalis [20].

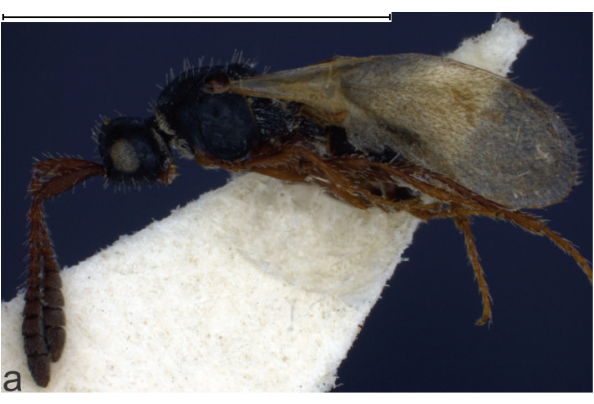

(a)

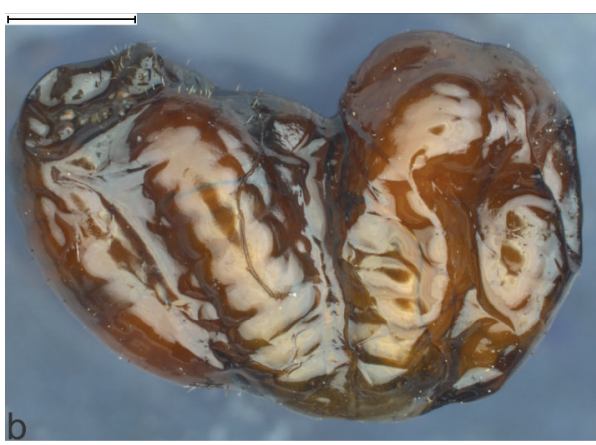

(b)

Figure 7: (a) Szelenyiopria pampeana female in lateral view. (b) Acromyrmex lobicornis larva showing immature instars of diapriines. Scale: $1 \mathrm{~mm}$.

3.1.11. Szelenyiopria Fabritius, 1974 [49]. Szelenyiopria Fabritius, 1974: 54 [49].

Gymnopria Loiácono, 1987: 130 [21].

Distribution. Wide distribution from Argentina to Guatemala $[21,49]$.

Biology. Szelenyiopria lucens (Loiácono) from Uruguay is the first member of the tribe Diapriini in the New World positively reared from ants. Loiácono [21] reports up to three wasps per mature larva of Acromyrmex ambiguus (Emery) (Attini). Members of Szelenyiopria show no specialized structures known among other myrmecophilic Diapriini; Masner and García [5] assumed that the specialized setae with truncate apices are outlet of chemical substances.

3.1.12. Szelenyiopria pampeana (Loiácono, 2000) [4] (Figure 7(a)). Gymnopria pampeana Loiácono, 2000: 10 in Loiácono et al., 2000 [4].

Szelenyiopria pampeana: Loiácono and Margaría, 2009: $63[8]$.

Distribution. Argentina (La Pampa) $[4,8]$.

Biology. Koinobiont and gregarious endoparasitoids of late instar larvae of Acromyrmex lobicornis (Emery), it was also established simultaneous parasitoidism with Trichopria sp. [4] (Figure 7(b)).

Material Studied. Holotype female, Argentina, Santa Rosa, 8XI-1995, Quirán and Corró Molas colls.; 25 paratypes females 
and 3 males, Lihuel Calel, 4-XII-1997, Quirán and Corró Molas colls.

3.1.13. Szelenyiopria reichenspergeri (Ferrière, 1929) [35].

Doliopria reinchespergeri Ferrière, 1929: 165 [35].

Szelenyiopria reinchespergeri: Fabritius, 1974, 54 [49].

Distribution. Argentina (Salta and Tucumán) [35, 49].

Biology. Associated with Eciton quadriglume and Neivamyrmex legionis (Smith) [35, 49].

Material Studied. One female, Argentina, Salta, 2-6-II-1950, Golbach coll.

\subsubsection{Szelenyiopria sp.}

Distribution. Argentina (Córdoba) (new record).

Material Studied. Female and 3 males with an ecitonine ant, Argentina, Córdoba, San Javier, La Paz, 1-20-I-1929, Bruch coll.

Remarks. Most females of this genus have 11-segmented antennae, but material studied here presents antenna 12segmented as mentioned by Masner and García [5] for undescribed species. We considered that these specimens belong to Szelenyiopria genus by the most important feature, the presence on entire body of specialized straight setae, truncate apically.

3.1.15. Trichopria Ashmead, 1893 [34]. Trichopria Ashmead, 1893: 407, 431 [34].

Ashmeadopria Kieffer, 1912: 8, 10, 59 [50].

Phaenopria Ashmead, 1893: 40, 436 [34].

Planopria Kieffer, 1906: 19 [51].

Orthopria Kieffer, 1911: 983, 984 [52]. Distribution. World-

wide [5].

Biology. Associated with the "fire ant," Solenopsis richteri Forel (Kieffer, 1921) and endoparasitoid of Acromyrmex lobicornis [4].

3.1.16. Trichopria formicans Loiácono, 2000 [4] (Figures 8(a) and $8(b)$ ). Trichopria formicans Loiácono 2000 in Loiácono et al., 2000: 12 [4].

Distribution. Argentina (La Pampa) [4].

Biology. Reared from larvae of Acromyrmex lobicornis [4].

Material Studied. Holotype female, Argentina, La Pampa, Utracán, 22-XII-1997, Caramuti y Rodriguez colls.; paratypes 68 females and 43 males (MLP), same data as holotype.

3.1.17. Trichopria myrmecophila (Kieffer, 1921) [12]. Phaenopria myrmecophila Kieffer, 1921: 4 [12].

Trichopria myrmecophila: De Santis in De Santis and Esquivel, 1966: 50 [16].

Distribution. Argentina (Buenos Aires) [12].

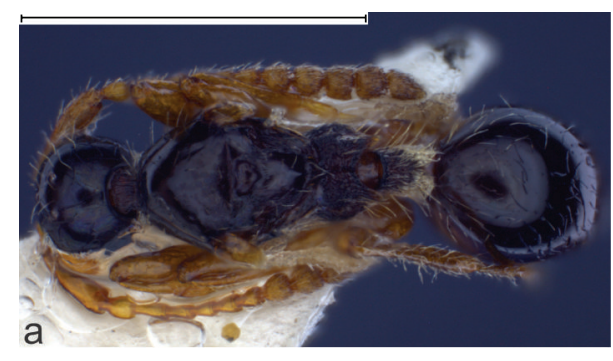

(a)

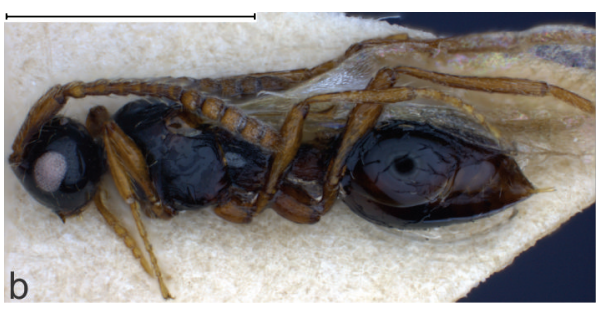

(b)

FIGURE 8: Trichopria formicans female (a) in dorsal view and (b) lateral view. Scale: $1 \mathrm{~mm}$.

Biology. Associated with Solenopsis richteri [12].

\subsubsection{Trichopria sp.}

Distribution. Argentina Buenos Aires.

Biology. Collected with the "argentine ant," Linepithema humile (new record).

Material Studied. Female collected with Linepithema humile, Argentina, Buenos Aires, J. C. Paz, 8-II-1940, Ogloblin coll.

Remarks. Masner studied this material and determined specimens as Trichopria s. str. sp.

\subsection{Tribe Spilomicrini Ashmead, 1893 [34]}

3.2.1. Bruchopria Kieffer, 1921 [12]. Bruchopria Kieffer, 1921: 38 [12].

Aulatopria Brèthes, 1927: 164 [53].

Distribution. Argentina (Buenos Aires, Córdoba, and Misiones) $[12,53]$.

Biology. Associated with ants of the genera Solenopsis Westwood (Solenopsidini) and Acromyrmex Mayr (Attini) [12].

Remarks. Hölldobler and Wilson [54] mentioned specimens of genus Bruchopria, as Solenopsis guest. Masner and García [5] mentioned "wings often bitten off by ants." Loiácono et al. [26] studied alated and dealated individuals of Bruchopria species. The action of dealation has not been observed. The presence of tegulae with normal development and wing stumps demonstrates that the apterism has a secondary origin, caused by the autotomy or by bites of the host ants. The apices of the wing stumps of all individuals examined were 


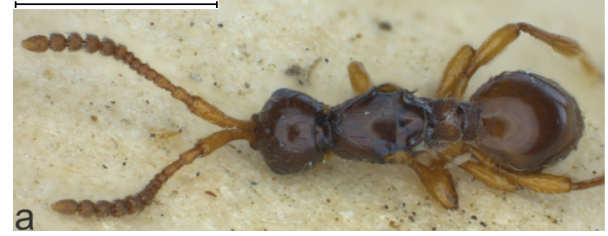

(a)

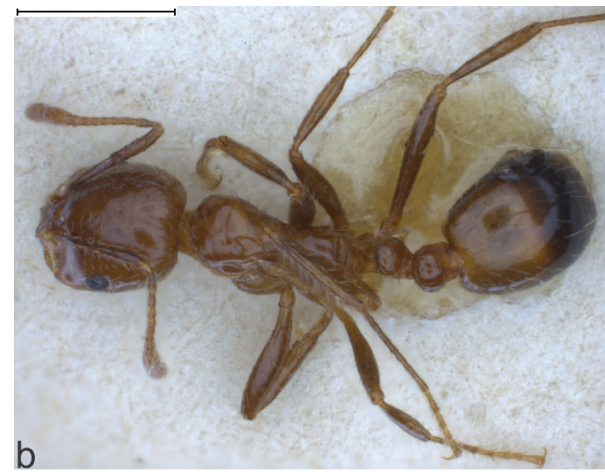

(b)

Figure 9: (a) Bruchopria hexatoma female dealate in dorsal view. (b) Solenopsis richteri. Scale: $1 \mathrm{~mm}$.

regular suggesting that the wings are bitten or torn off close to the tegulae. The fact that specimens are dealated allows them to move into the mound galleries and chambers.

3.2.2. Bruchopria hexatoma Kieffer, 1921 [12] (Figures 9(a), 10(a), and 10(b)). Bruchopria hexatoma Kieffer, 1921: 39 [12].

Bruchopria hexatoma: Borgmeier, 1939: 543 [44].

Distribution. Argentina (Misiones, Córdoba and Buenos Aires) $[12,44]$.

Biology. Associated with Solenopsis richteri (Figure 9(b)) and Acromyrmex lundii $[12,44]$.

Material Studied. One female dealated, Argentina, Misiones, Pastoreo Grande, 9-VII-1932, Ogloblin coll.; 1 female dealated, Argentina, Córdoba, XII-1920, Bruch coll., 1 female dealated, Córdoba, Sierras de Córdoba, La Granja, Bruch coll., without date; 1 male dealated, Argentina, Buenos Aires, without locality, 9-VII-1923, Bruch coll., with the ant; 4 females dealated, Argentina, Buenos Aires, Olivos, without date, Bruch coll., with the ant; 1 female dealated, Argentina, Buenos Aires, 10-IX-1925, Bruch coll.; 1 female dealated with Acromyrmex lundii, Argentina, Buenos Aires, without date, Bruch coll.

Remarks. Bruchopria hexatoma has been reported by Kieffer [12] in association with Solenopsis richteri and Acromyrmex lundii in Argentina; Borgmeier [44] also mentioned this species as a guest of S. saevissima (Smith), in Brazil.

The specimens from the provinces of Córdoba and Buenos Aires are dealated, with remains of wings (Figures 10(a) and 10(b)), and most of them are accompanied by the host ants (Figure 9(b)). Unfortunately, the types of the species

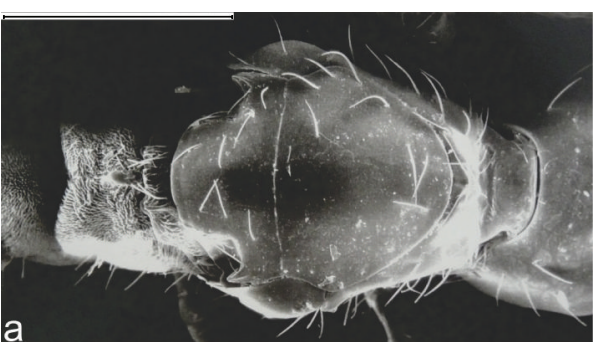

(a)

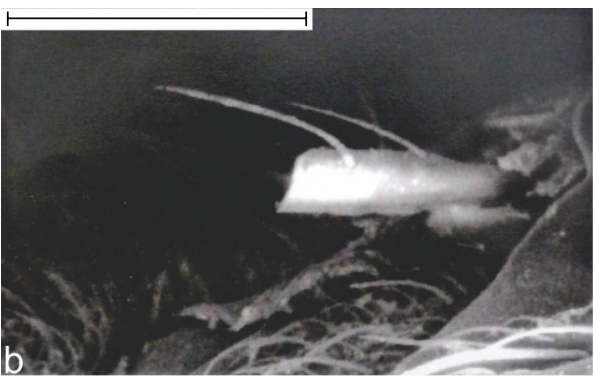

(b)

FIgURE 10: Bruchopria hexatoma female. (a) mesosoma and petiole in dorsal view, scale: $0.5 \mathrm{~mm}$; (b) wing stump, scale: $0.1 \mathrm{~mm}$ [26]

described by Kieffer have become widely scattered or lost [55]. Bruch sent to Kieffer part of the same series of material to identify (De Santis, pers. comm.).

3.2.3. Bruchopria pentatoma Kieffer, 1921 [12]. Bruchopria pentatoma Kieffer, 1921: 38 [12].

Distribution. Argentina (Córdoba) [12].

Biology. Associated with Solenopsis richteri [12].

Material Studied. Syntype male dealated, Argentina, Córdoba, Alta Gracia; 1-8-IV-1920, Bruch coll.

Remarks. According to Kieffer's description, females of both species, $B$. pentatoma and $B$. hexatoma, are distinguished by the number of club antennomeres, five and six, respectively. Unfortunately, the unique female type is not available. Bruchopria pentatoma has also been reported by Kieffer [12] in association with S. richteri and Acromyrmex lundii (Guérin) in Argentina.

3.2.4. Pentapria Kieffer, 1905 [56]. Pentapria Kieffer, 1905: 34 [56].

Antipapria Fabritius, 1968: 844 [57].

Bakeria Kieffer, 1905: 34 [56].

Plutopria Kieffer, 1910: 48 [40].

Spilomicrinus Ogloblin, 1957: 425 [58].

Xenopria Fouts, 1939: 260 [59].

Distribution. The genus is distributed in the New World [5].

Biology. The principal host plausible to assume is Stratiomyidae (Diptera) [5]. Herein, we studied a female collected with Solenopsis saevissima (Hymenoptera: Formicidae). 
TABLE 1

\begin{tabular}{|c|c|c|c|c|c|}
\hline Diapriid tribe & Diapriids species & Argentine provinces & Ant subfamily & Ant tribe & Ant species \\
\hline \multirow{12}{*}{ Diapriini } & Asolenopsia rufa & $\begin{array}{l}\text { Córdoba, Entre Ríos, } \\
\text { Santa Fe }\end{array}$ & Ecitoninae & Ecitonini & Neivamyrmex carettei \\
\hline & Basalys sp. & Buenos Aires & Dolichoderinae & Dolichoderini & Linepithema humile \\
\hline & Doliopria collegii & Buenos Aires, Misiones & Ecitoninae & Ecitonini & $\begin{array}{l}\text { Eciton burchellii, Eciton } \\
\text { quadriglume }\end{array}$ \\
\hline & Doliopria myrmecobia & Buenos Aires, Misiones & Myrmicinae & Attini & Acromyrmex lundii \\
\hline & Notoxoides pedissequus & Córdoba & Ecitoninae & Ecitonini & Neivamyrmex pseudops \\
\hline & Notoxoides pronotalis & $\begin{array}{l}\text { Córdoba, Salta, San Luis, } \\
\text { Santiago del Estero }\end{array}$ & Ecitoninae & Ecitonini & $\begin{array}{l}\text { Eciton dulcium, } \\
\text { Neivamyrmex sulcatus }\end{array}$ \\
\hline & Szelenyiopria pampeana & La Pampa & Myrmicinae & Attini & Acromyrmex lobicornis \\
\hline & Szelenyiopria reichenspergeri & Salta, Tucumán & Ecitoninae & Ecitonini & $\begin{array}{l}\text { Eciton quadriglume, } \\
\text { Neivamyrmex legionis }\end{array}$ \\
\hline & Szelenyiopria sp. & Córdoba & Ecitoninae & Ecitonini & Ecitonini sp. \\
\hline & Trichopria formicans & La Pampa & Myrmicinae & Attini & Acromyrmex lobicornis \\
\hline & Trichopria myrmecophila & Buenos Aires & Myrmicinae & Solenopsidini & Solenopsis richteri \\
\hline & Trichopria sp. & Buenos Aires & Dolichoderinae & Dolichoderini & Linepithema humile \\
\hline \multirow{4}{*}{ Spilomicrini } & Bruchopria hexatoma & $\begin{array}{l}\text { Buenos Aires, Córdoba, } \\
\text { Misiones }\end{array}$ & $\begin{array}{l}\text { Myrmicinae } \\
\text { Myrmicinae }\end{array}$ & $\begin{array}{l}\text { Solenopsidini } \\
\text { Attini }\end{array}$ & $\begin{array}{l}\text { Solenopsis richteri } \\
\text { Acromyrmex lundii }\end{array}$ \\
\hline & Bruchopria pentatoma & Córdoba & Myrmicinae & Solenopsidini & Solenopsis richteri \\
\hline & Pentapria cf. nodicornis & Córdoba & Myrmicinae & Solenopsidini & Solenopsis saevissima \\
\hline & Spilomicrus sp. & Buenos Aires & Myrmicinae & Solenopsidini & Solenopsidini sp. \\
\hline
\end{tabular}

\subsubsection{Pentapria cf. nodicornis}

Distribution. Argentina (Córdoba).

Biology. Associated with Solenopsis saevissima (new record).

Material Studied. Female collected with Solenopsis saevissima, Argentina, Córdoba, Alta Gracia, La Granja, II-1927, Bruch. coll., with no more data.

3.2.6. Spilomicrus Westwood, 1832 [36]. Spilomicrus Westwood, 1832: 129 [36].

Loxotropa Foerster, 1856: 122, 123, 126 [60].

Hoplopria Ashmead, 1893: 385, 386, 388 [34].

Linkiola Kieffer, 1910: 39 [40].

Eriopria Kieffer, 1910: 693, 744 [40].

Tritopria Kieffer, 1910: 717, 748 [40].

Cologlyptus Crawford, 1910: 123 [61].

Scutellipria Szabó, 1961: 53-493 [62].

Distribution. America [5].

Biology. Primary parasitoidism solitary and gregarious of various Diptera; few species were reared from Coleoptera [5]. Herein, we studied samples associated with a Solenopsidini ant.

\subsubsection{Spilomicrus sp.}

Distribution. Argentina (Buenos Aires).
Biology. Associated with Solenopsidini ant.

Material Studied. Two females with a Solenopsidini ant, Argentina, Buenos Aires, 9-VIII-1923, Bruch coll.

Table 1 summarizes information about diapriids and their associates.

\section{Discussion}

The knowledge of the biology and behavior of these myrmecophilic diapriids and the nature of their interactions with ants has progressed in Argentina since 1980 [63] to present. There are nine genera recorded from Argentina, which represents about $50 \%$ of the genera mentioned by Masner and García [5] from the New World.

The study of Diapriidae Collection housed at División Entomología of Museo de La Plata, which includes Bruch and Ogloblin myrmecophilic diapriid specimens, allowed us to report 16 species of nine genera of Diapriinae associated with ants in Argentina. It is interesting to highlight that Asolenopsia rufa, Notoxoides pronotalis, Bruchopria pentatoma, and $B$. hexatoma are the species with a high degree of integration with the host ants, adaptation being both morphological and behavioral.

We mentioned for the first time the associations between the "argentine ant," Linepithema humile, and both Basalys sp. and Trichopria sp., Pentapria cf. nodicornis and Solenopsis saevissima, and Spilomicrus sp. and Solenopsidini ant.

Doliopria myrmecobia is a new record to Misiones. The only described species of Szelenyiopria occurs in La Pampa 
province, S. pampeana; an undescribed species is known to us from Córdoba.

We considered that Szelenyiopria pampeana and Trichopria formicans parasitoids of Acromyrmex species in Argentina seem excellent potential models to explore how parasitoids impact ant colony demography, population biology, and ant community structure.

\section{Acknowledgments}

The authors would like to thank Dr. J.-P. Lachaud for inviting them to participate in the Special Issue of Psyche, "Ants and Their Parasites 2013." Special thanks go to Consejo Nacional de Investigaciones Científicas y Técnicas (CONICET) and Secretaría de Ciencia y Técnica de la Universidad Nacional de La Plata (UNLP) for financial support, Dr. Carlos Margaría for his critical reading of the paper, and to reviewers for their suggestions.

\section{References}

[1] L. Huggert and L. Masner, "A review of myrmecophilicsymphilic diapriid wasps in the Holarctic realm, with descriptions of new taxa and a key to genera (Hymenoptera: Proctotrupoidea: Diapriidae)," Contributions of the American Entomological Institute, vol. 20, pp. 63-89, 1983.

[2] L. Masner, "A revision of Ecitophilous Diapriid-genus Mimopria Holmgren (Hym., Proctotrupoidea)," Insectes Sociaux, vol. 6, no. 4, pp. 361-367, 1959.

[3] J. P. Lachaud and G. Pérez-Lachaud, "Diversity of species and behavior of hymenopteran parasitoids of ants, a review," Psyche, vol. 2012, Article ID 134746, 24 pages, 2012.

[4] M. S. Loiácono, C. B. Margaría, E. M. Quirán, and B. Corró Molas, "Diápridos (Hymenoptera) parasitoides de larvas de la hormiga cortadora Acromyrmex lobicornis (Hymenoptera: Formicidae) en la Argentina," Revista de la Sociedad Entomológica Argentina, vol. 59, pp. 7-15, 2000.

[5] L. Masner and J. L. García, "The genera of Diapriinae (Hymenoptera: Diapriidae) in the new world," Bulletin of the American Museum of Natural History, no. 268, pp. 2-125, 2002.

[6] M. Yoder, "Mannomicrus (Hymenoptera: Diapriidae), a new genus of myrmecophilic diapriid, with a digital version of Masner and García’s (2002) key to New World Diapriinae and an illustration of digital description and key markup using an ontology," Zootaxa, no. 1439, pp. 47-55, 2007.

[7] B. Pérez-Ortega, H. Fernández-Marín, M. S. Loiácono, P. Galgani, and W. T. Wcislo, "Biological notes on a fungusgrowing ant, Trachymyrmex cf. zeteki (Hymenoptera, Formicidae, Attini) attacked by a diverse community of parasitoid wasps (Hymenoptera, Diapriidae)," Insectes Sociaux, vol. 57, no. 3, pp. 317-322, 2010.

[8] M. S. Loiácono and C. Margaría, "A note on Szelenyiopria Pampeana (Loiácono) n. comb., parasitoid wasps (Hymenoptera: Diapriidae) attacking the fungus growing ant, Acromyrmex lobicornis Emery (Hymenoptera: Formicidae: Attini) in La Pampa, Argentina," Zootaxa, vol. 2105, pp. 63-65, 2009.

[9] H. Fernández-Marín, J. K. Zimmerman, and W. T. Wcislo, "Acanthopria and Mimopriella parasitoid wasps (Diapriidae) attack Cyphomyrmex fungus-growing ants (Formicidae, Attini)," Naturwissenschaften, vol. 93, no. 1, pp. 17-21, 2006.
[10] A. Lanteri and J. Martínez, "Prohombres del Museo de la Plata: Carlos Bruch, organizador de la división entomología," Revista de la Sociedad Entomológica Argentina, vol. 71, no. 3-4, pp. 179$185,2012$.

[11] http://gap.entclub.org/taxonomists/Bruch/index.html, 2012.

[12] J. J. Kieffer, "Proctotrypides hôtes des fourmis en Argentine," Anales de la Sociedad Científica Argentina, vol. 91, pp. 36-41, 1921.

[13] J. J. Kieffer, “Trois nouveaux Hymenoptères d'Argentine recuellis par C. Bruch," Anales de la Sociedad Científica Argentina, vol. 94, pp. 205-208, 1922.

[14] S. V. Triapitsyn, J. T. Huber, G. A. Logarzo, V. V. Berezovskiy, and D. A. Aquino, "Review of Gonatocerus (Hymenoptera: Mymaridae) in the Neotropical region, with description of eleven new species," Zootaxa, no. 2456, pp. 1-243, 2010.

[15] M. S. Loiácono and C. B. Margaría, "Grado de curadoría de la colección de Diapriidae (Hymenoptera) del Museo de la Plata, Argentina," Revista de la Sociedad Entomológica Argentina, vol. 70, no. 3-4, pp. 293-300, 2011.

[16] L. De Santis and L. Esquivel, “Tercera lista de himenópteros parásitos y predatores de los insectos de la República Argentina," Revista del Museo de la Plata, vol. 9, pp. 47$215,1966$.

[17] L. De Santis, "Catálogo de los himenópteros argentinos de la Serie Parasítica, incluyendo Bethyloidea," Publicación de la Comisión de Investigaciones Científicas de la Provincia de Buenos Aires, pp. 1-337, 1967.

[18] L. De Santis, "Nuevas citas de himenópteros para la República Argentina," Revista de la Facultad de Agronomía, vol. 3, no. 47, pp. 201-207, 1971.

[19] M. S. Loiácono, "Diápridos ecitófilos sinfilos de la región Neotropical (Hymenoptera - Proctotrupoidea - Diapriidae)," Revista de la Sociedad Entomológica Argentina, vol. 40, pp. 297310, 1981.

[20] M. S. Loiácono, "Notas sobre Diapriinae neotropicales (Hymenoptera, Diapriidae)," Revista de la Sociedad Entomológica Argentina, vol. 40, pp. 237-241, 1981.

[21] M. S. Loiácono, "Un nuevo diáprido (Hymenoptera) parasitoide de larvas de Acromyrmex ambiguus (Emery) (Hymenoptera, Formicidae) en el Uruguay," Revista de la Sociedad Entomológica Argentina, vol. 44, pp. 129-136, 1987.

[22] M. S. Loiácono and N. B. Díaz, "Los ejemplares tipo de Proctotrupoidea y Ceraphronoidea (Hymenoptera) depositados en la colección del Museo de la Plata," Revista del Museo de la Plata, Serie Técnica y Didáctica, vol. 23, pp. 1-13, 1996.

[23] M. S. Loiácono, "Diaprinos asociados a la hormiga Camponotus rufipes (Hymenoptera: Diapriidae)," Revista de la Sociedad Entomológica Argentina, vol. 59, pp. 198-200, 2000.

[24] M. S. Loiácono and C. B. Margaría, "Systematic study of the genus Gymnopria (Hymenoptera: Diapriidae)," Insect Systematic Evolution, vol. 31, no. 2, pp. 187-200, 2000.

[25] M. S. Loiácono and C. B. Margaría, "Ceraphronoidea, Platygastroidea, and Proctotrupoidea from Brazil (Hymenoptera)," Neotropical Entomology, vol. 31, no. 4, pp. 551-560, 2002.

[26] M. S. Loiácono, C. B. Margaría, E. Quirán, and B. Corró Molas, "Revision of the myrmecophilous diapriid genus Bruchopria Kieffer (Hymenoptera, Proctotrupoidea, Diapriidae)," Revista Brasileira de Entomologia, vol. 46, no. 3, pp. 231-235, 2002.

[27] M. S. Loiácono, C. B. Margaría, N. B. Díaz, and F. E. Gallardo, "Lista de himenópteros parasitoides y depredadores de los insectos de la República Argentina primer suplemento, por 
De Santis, L. y C. Monetti," in Contribuciones Taxonómicas en órdenes de Insectos Hiperdiversos, J. L. Bousquets and A. Lanteri, Eds., pp. 91-139, Universidad Nacional Autónoma de México (UNAM) and RIBES-CYTED (Red Iberoamericano de Biogeografía y Entomología Sistemática-Programa Iberoamericano de Ciencia y Tecnología para el Desarrollo), Mexico City, Mexico, 2008.

[28] M. Loiácono and C. Margaría, "Diapriidae," in Biodiversidad de Artrópodos Argentinos, L. Claps and S. Roig-Juñent, Eds., vol. 2, 2012.

[29] M. Loiácono, C. Margaría, D. O. Moreira, and D. Aquino, "A new species of Szelenyiopria Fabritius (Hymenoptera: Diapriidae), larval parasitoid of Acromyrmex subterraneus subterraneus (Forel) (Hymenoptera: Formicidae) from Brazil," Zootaxa. In press.

[30] A. Hadley, 2011, http://www.hadleyweb.pwp.blueyonder.co.uk/ $\mathrm{CZM} /$ combinezm.htm.

[31] M. J. Sharkey, "Phylogeny and classification of Hymenoptera," in Linnaeus Tercentenary: Progress in Invertebrate Taxonomy, Z.Q. Zhang and W. A. Shear, Eds., vol. 1668, pp. 521-548, Zootaxa, Auckland, New Zealand, 2007.

[32] B. Bolton, Bolton's Catalogue of Ants of the World, 1758, 2005, Harvard University Press, Cambridge, Mass, USA, 2006.

[33] M. J. Yoder, K. Dole, and A. R. Deans, "mx-A collaborative content management system for revisionary systematists'm," 2006, http://www.diapriid.org/.

[34] W. H. Ashmead, "Monograph of the North American Proctotrypidae," United States National Museum Bulletin, vol. 45, pp. 1-472, 1893.

[35] C. Ferrière, "Nouveaux diapriides du Brésil, hôtes des Eciton," Zoologischer Anzeiger, vol. 82, pp. 156-171, 1929.

[36] J. O. Westwood, "Descriptions of several new British forms amongst the parasitic hymenopterous insects," London \& Edingburgh Philosophical Magazine and Journal of Science, vol. 1, pp. 127-129, 1832.

[37] J. J. Kieffer, “Serphides des Îles Philippines," Insecta, vol. 3, pp. 253-260, 1913.

[38] L. Masner, "A redescription of three species of Proctotrupoidea (Hymenoptera) from Jurine's collection," Entomophaga, vol. 9, no. 1, pp. 81-89, 1964.

[39] F. Muesebeck and L. M. Walkley, "Type species of the genera and subgenera of parasitic wasps comprising the superfamily Proctotrupoidea (order Hymenoptera)," Proceedings of the United States Natural Museum, vol. 105, no. 3359, pp. 319-419, 1956.

[40] J. J. Kieffer, "Beschreibung neuer südamerikanischer im Zoologischen Museum zu Berlin aufbewahrter Diapriiden," Entomologische Rundschau, vol. 27, pp. 39-56, 1910.

[41] J. Risbec, "La faune entomologique des cultures au Sénégal et au Soudan: II. Contribution à l'étude des Proctotrupidae (Serphiidae)," Gouvernement général de l'Afrique occidentale française, [s.l.], pp. 509-638, 1950.

[42] W. H. Ashmead, "Classification of the pointed-tailed wasps, or the superfamily Proctotrypoidea- II," Journal of the New York Entomological Society, vol. 11, p. 30, 1903.

[43] J. Brèthes, "Himenópteros Argentinos," Anales del Museo Nacional de Historia Natural de Buenos Aires, vol. 20, pp. 205316, 1911.

[44] T. Borgmeier, "Sobre algunos Diapriideos myrmecophilos, principalmente do Brasil (Hym. Diapriidae)," Revista de Entomologia, vol. 10, no. 3, pp. 530-545, 1939.
[45] L. Masner, "A new genus of ecitophilous diapriid wasps from Arizona (Hymenoptera: Proctotrupoidea: Diapriidae)," Canadian Entomologist, vol. 109, no. 1, pp. 33-36, 1977.

[46] C. Bruch, "Estudios mirmecológicos," Anales del Museo Nacional de Historia Natural, vol. 34, pp. 341-360, 1928.

[47] C. Bruch, "Estudios mirmecológicos con la descripción de nuevas especies de dípteros (Phoridae) por los Rr. Pp. H. Schmitz y Th. Borgmeier y de una araña (Gonyleptidae) por el Doctor Mello-Leitão," Revista del Museo de la Plata, vol. 27, pp. 172-220, 1923.

[48] J.-P. Lachaud, "Etude des relations hôte-myrmécophile entre les Diapriidae Lepidopria pedestris Kieffer et Solenopsia imitatrix Wasmann et la fourmi Diplorhoptrum fugax Latreille [Ph.D. thesis]," Paul Sabatier, Toulouse, France, 1981.

[49] K. Fabritius, "Die Gattung Doliopria Kieffer 1910 und nebenstehende Gattungen (Hymenoptera: Diapriidae)," Folia Entomologica Hungarica, vol. 27, pp. 53-57, 1974.

[50] J. J. Kieffer, "Hymenoptera fam. Diapriidae," in Genera Insectorum, P. Wytsman, Ed., vol. 124, pp. 1-75, Fascicle, Burlingame, Calif, USA, 1912.

[51] J. J. Kieffer, "Description de quelques nouveaux serphides," Bulletin de la Societe D'Histoire Naturelle de Metz, vol. 25, pp. 1-7, 1906.

[52] J. J. Kieffer, "Species des Hyménoptères d'Europe et d'Algérie," in Librerie Scientifique A, E. André, Ed., vol. 10, pp. 913-1015, Hermann \& Fils, París, France, 1911.

[53] J. Brèthes, "Parásitos e hiperparásitos de "Diatraea saccharalis" en la caña de azúcar, en Tucumán," Revista Industrial y Agrícola de Tucumán, vol. 17, pp. 63-66, 1927.

[54] B. Hölldobler and E. O. Wilson, The Ants, Harvard University Press, Cambridge, Mass, USA, 1990.

[55] L. Masner, "The types of Proctotrupoidea (Hymenoptera) in the British Museum (Nat. Hist.) and Hope Department of Entomology (Oxford)," Bulletin of the British Museum, vol. 1, pp. $1-154,1965$.

[56] J. J. Kieffer, "Nouveaux Proctotrypides exotiquez conservés au Musée Civique de Gênes," Annali del Museo Civico di Storia Naturale di Genova, vol. 2, no. 2, pp. 9-39, 1905.

[57] K. Fabritius, "Antipapria n. gen., eine neue Diapriiden-Gattung aus Argentinien (Hymenoptera, Proctotrupoidea)," Travaux du Muséum d'Histoire Naturelle "Grigore Antipa", vol. 8, pp. 841844, 1968.

[58] A. Ogloblin, "Los Insectos de las Islas Juan Fernández. 35. Mymaridae, Ceraphronidae, Diapriidae y Scelionidae (Hymenoptera)," Revista Chilena Entomología, vol. 5, pp. 413444, 1957.

[59] R. M. Fouts, "Descriptions of one new genus and three new species of Diapriidae (Hymenoptera)," Proceedings of the Entomological Society of Washington, vol. 41, pp. 260-263, 1939.

[60] A. Foerster, "Hymenopterologische studien," in Chalcidiae und Proctotrupii, vol. 2 of II. Heft. Aachen, pp. 1-152, Ernsteer Meer, Zoeterwoude, The Netherlands, 1856.

[61] J. C. Crawford, "New Hymenoptera from the Philippine Islands," Proceedings of the United States National Museum, vol. 38, no. 1733, pp. 119-133, 1910.

[62] J. B. Szabó, "Neue paläarktische Gattungen und Arten der Diapriiden in der Sammlung des Ungarischen Naturwissenschaftlichen Museums (Hymenoptera, Proctotrupoidea, Diapriidae)," Annales Historico-Naturales Musei Nationalis Hungarici, vol. 53, pp. 491-494, 1961. 
[63] L. De Santis, "Entomología: evolución de las ciencias en la República Argentina 1923-1972," Publicación de la Sociedad Científica Argentina, vol. 12, pp. 1-323, 1992. 

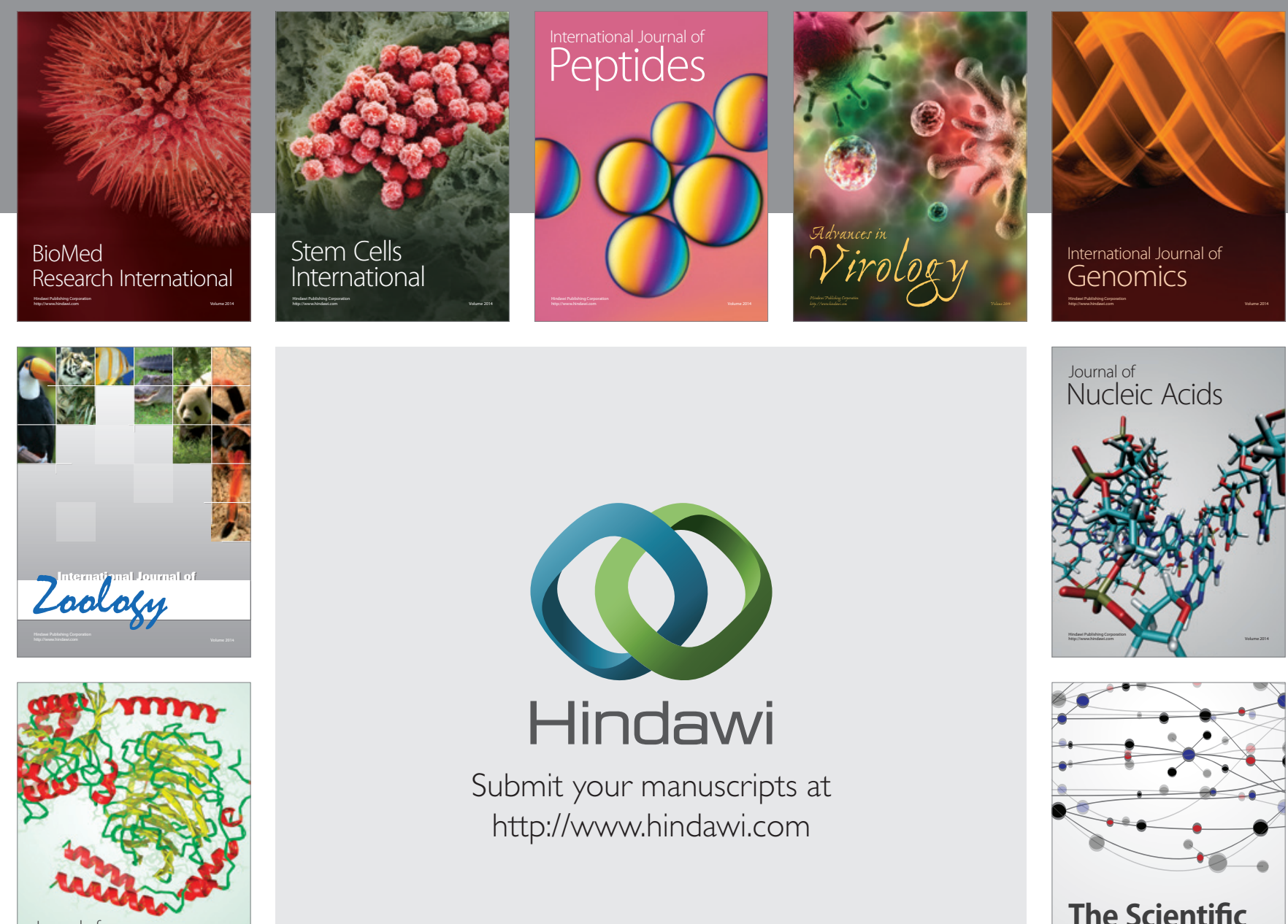

Submit your manuscripts at

http://www.hindawi.com

Journal of
Signal Transduction
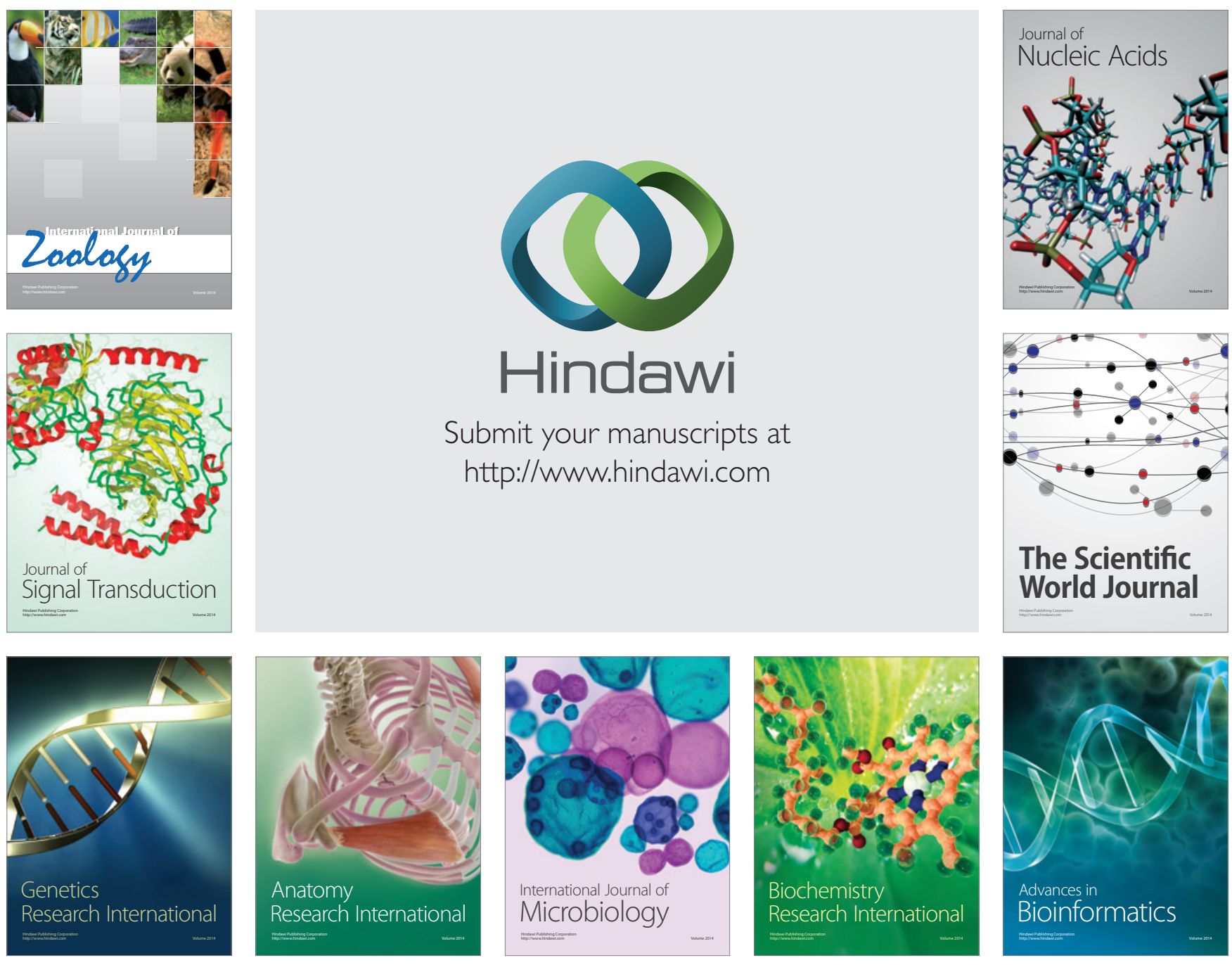

The Scientific World Journal
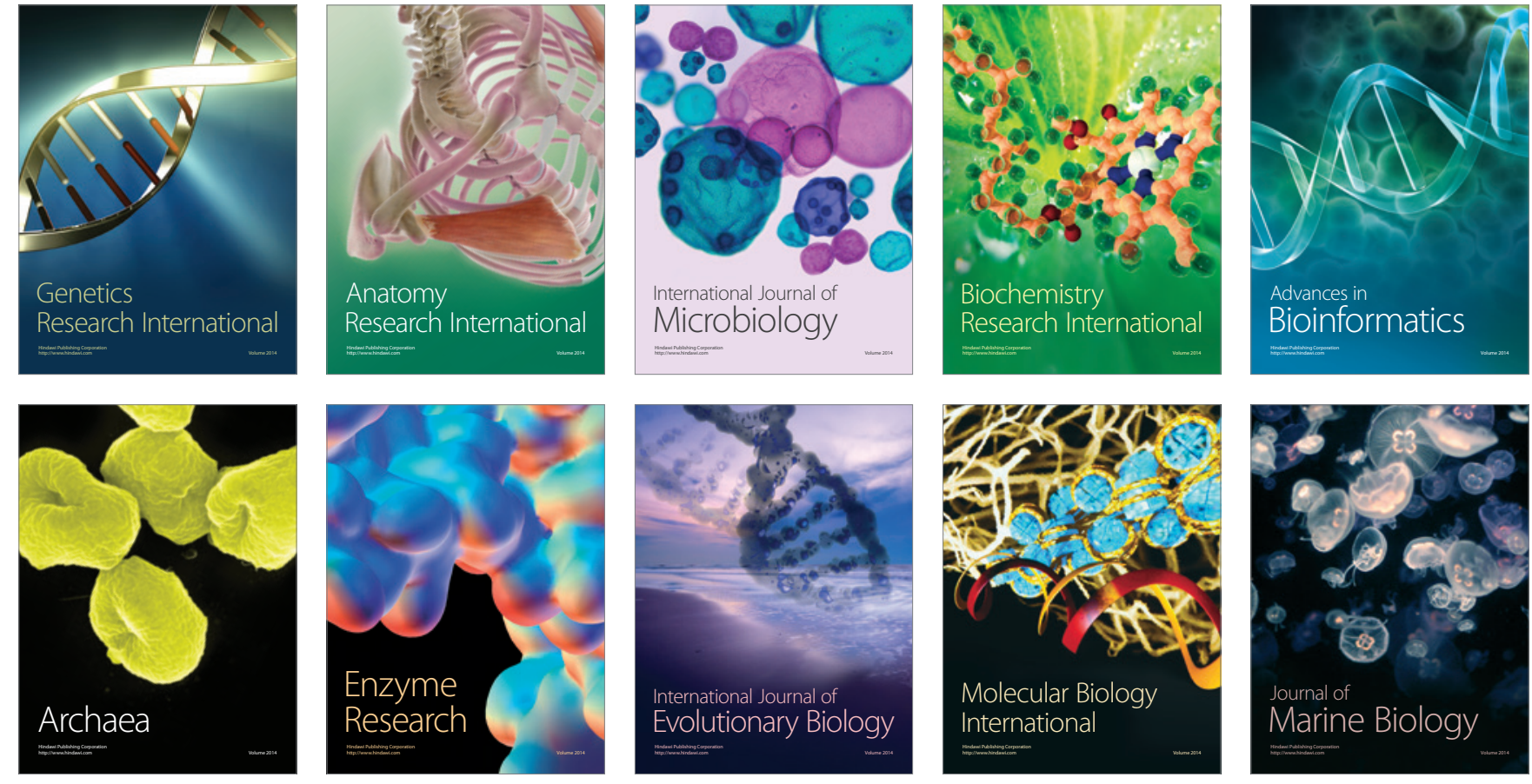